\title{
IMPROVING THE EFFICIENCY OF DISTILLATION AND RECTIFICATION EQUIPMENT
}

\author{
A. Ukrainets, P. Shiyan, Y. Buliy, A. Kuts \\ National University of Food Technologies
}

\begin{tabular}{l} 
Key words: \\
Plates \\
Column \\
Heated steam \\
Main fraction \\
Alcohol impurities \\
Controlled cycles \\
\hline \multicolumn{1}{c}{ Article history: } \\
Received 16.11.2018 \\
Received in revised form \\
03.12.2018 \\
Accepted 20.12.2018 \\
\hline
\end{tabular}

Corresponding author:
A. Ukrainets
E-mail:
npnuht@ukr.net

\begin{abstract}
The effectiveness of the contact devices reduces the inadequate contact time of the vapor and liquid, as well as the mixing of the liquid on adjacent plates. The use of plates with partial compensation of direct flow does not solve the problem.
\end{abstract}

The authors propose the technology of rectification with controlled cycles of fluid retention on the plates, which allows to change the vapor velocity in the contact element slits by changing the section of the plates in such a way that during the period of fluid overflow the plate becomes leaky.

The purpose of the work was to investigate the effectiveness of contact devices with variable sections in the process of dispersing the main fraction and distilling the mash while increasing the residence time of the liquid on the plates.

The research was conducted in the production conditions of the State Enterprise "Chudnovsky Alcohol Plant". The experimental column was equipped with scales and the contact devices were movable valves, which alternately closed and opened the overflow holes according to the given algorithm. The paper presents the results of studies of the distribution of key volatile impurities of alcohol at the height of the accelerating column. It is proved that with a delay of liquid up to $20 \mathrm{sec}$. the degree of removal of aldehydes, higher alcohols of fusel oil and methyl alcohol increased by an average of $30 \%$, the multiplicity of concentration of the main and upper intermediate impurities increased by $32 \%$. The delay of the bracket on the plates of the graphic column to $12 \mathrm{sec}$. leads to an increase in the concentration of braided distillate by $28 \%$.

Extension of the residence time of the liquid on plates of the accelerating column to $20 \mathrm{sec}$., and the mash column up to $12 \mathrm{sec}$. allows to increase the efficiency of contact devices and the degree of separation of alcohol-containing fractions by an average of $30 \%$, as well as reduce the specific costs of heated steam to $32 \%$ compared to typical installations.

DOI: $10.24263 / 2225-2924-2018-24-6-20$ 


\title{
ПІДВИЩЕННЯ ЕФЕКТИВНОСТІ БРАГОРЕКТИФІКАЦІЙНИХ УСТАНОВОК
}

\author{
А.І. Українець, П.Л. Шиян, Ю.В. Булій, А.М. Куц \\ Національний університет харчових технологій
}

Ефективність роботи контактних пристроїв знижують недостатній час контакту пари та рідини, а також перемішування рідини на суміжних тарілках. Використання тарілок з частковою компенсаџією прямотоку не вирімує проблему.

Авторами запропонована технологія ректифікації з контрольованими ииклами затримки рідини на тарілках, яка дає змогу змінювати швидкість пари в щілинах контактних елементів завдяки зміні живого перерізу тарілок таким чином, щзо в період переливу рідини тарілка стає провальною. Для иього було досліджено ефективність роботи контактних пристроїв із змінним живим перерізом у прочесах розгонки головної фракції та перегонки зрілої бражки при подовженні часу перебування рідини на тарілках.

Дослідження проводились у виробничих умовах ДП «Чуднівський спиртовий завод». Експериментальна колона була оснащена лускоподібними тарілками, а контактні пристрої - рухомими клапанами, які почергово закривали та відкривали переливні отвори згідно із заданим алгоритмом.

В статті представлені результати досліджень розподілення ключових летких домішок спирту по висоті розгінної колони. Доведено, щцо при затримиі рідини до 20 с ступінь вилучення альдегідів, вищих спиртів сивушного масла та метилового спирту зростала в середньому на 30\%, кратність концентрування головних та верхніх проміжних домішок підвищувалась на $32 \%$. Затримка бражки на тарілках бражної колони до 12 с призводила до підвищення концентрації бражного дистиляту на 28\%.

Подовження часу перебування рідини на тарілках розгінної колони до $20 \mathrm{c}$, а бражної колони - до 12 с дає змогу підвищити ефективність роботи контактних пристроїв та ступінь розділення спиртовмісних фракиій в середньому на $30 \%$, а також скоротити питомі витрати гріючої пари на $32 \%$ порівняно з типовими установками.

Ключові слова: тарілки, колона, гріюча пара, головна фракція, леткі домішки спирту, контрольовані ичикли.

Постановка проблеми. У брагоректифікаційних установках (БРУ) застосовують тарілчасті контактні пристрої, на яких послідовно здійснюється ступінчастий контакт фаз. Їх ефективність оцінюють за ступенем розділення суміші, що підлягає перегонці, пропускною здатністю пари й рідини, діапазоном сталої роботи, питомою витратою гріючої пари для здійснення масообміну тощо. Контактні пристрої повинні відповідати таким вимогам: забезпечувати на поверхні тарілки запас рідини (рідинну затримку), досягнення необхідної роздільної здатності при зміні навантаження за парою або рідиною, малий гідравлічний опір паровому потоку, можливість роботи брагоректифікацій- 
ного обладнання в різних адіабатичних умовах, унеможливлює винесення рідини 3 нижніх тарілок на верхні. Мірою оцінки ефективності реальної тарілки є іiі коефіцієнт корисної дії (ККД), який залежить від конструкції, діаметра, вільного перерізу колони, ііі навантаження, відстані між тарілками, швидкості пари, фізичних властивостей суміші, що підлягає розділенню тощо. ККД визначають дослідним шляхом. Для більшості тарілок його значення знаходиться в межах від 0,4 до 0,6 [1].

У виробничій практиці відомо сотні різних конструкцій тарілок, які класифікують за способом переливу рідини, способом взаємодії пари й рідини, за характером диспергування контактуючих фаз і конструкцією для вводу пари в рідину. Тарілки можуть бути гратчастими, ситчастими, лускоподібними, ковпачковими, клапанними, жалюзійними тощо. Підвищення ККД тарілок може бути досягнуто шляхом створення розвинутої поверхні фаз на ступенях контакту та інтенсифікації турбулізації парорідинної суміші [2].

За останні десятиліття запропоновано значну кількість нових контактних пристроїв, особливості яких ще недостатньо досліджені: клапанні тарілки EDV, тарілки Кіттеля, пристрої ударно-розпилювальної дії, кільцеві, лабіринтні пристрої тощо (рис. 1).
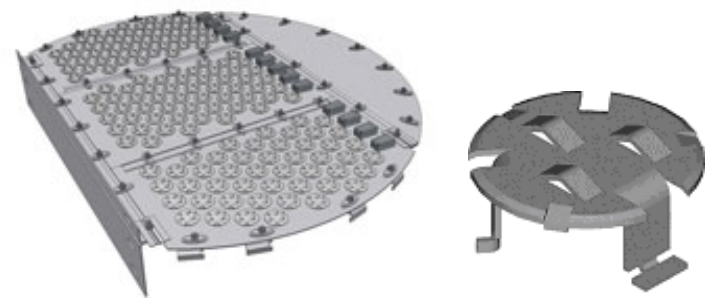

Рис. 1. Клапанні тарілки EDV

Технологічні розрахунки БРУ припускають миттєве перенесення летких компонентів пари та рідини і не враховують інтервал контакту фаз або тривалість перебування потоків на тарілці, необхідну для досягнення стану, близького до рівноважного. Використання тарілок з частковою компенсацією прямотоку не вирішує проблему. Для повного оновлення міжфазової поверхні на ступенях контакту, ідеального витіснення по парі й рідині, забезпечення максимального насичення пари легколеткими компонентами рідини, а рідини важколеткими компонентами пари та унеможливлення перемішування рідини на суміжних тарілках необхідною умовою $є$ подовження часу контакту пари та рідини на визначений термін часу та здійснення іiі циклічного переливу. Час рідинної затримки визначається дослідним шляхом. У вищевказаних умовах зростає рушійна сила процесу масообміну через збільшення градієнта концентрацій летких компонентів, покращуються дифузійні характеристики тарілок і підвищується ефективність їх роботи [3].

Враховуючи вищенаведене, авторами була запропонована технологія ректифікації в режимі роздільного руху фаз, що передбачає контрольовані цикли затримки рідини на тарілках колонного обладнання БРУ і синхронного iï переливу з парних і непарних за порядком розташування тарілок у два 
послідовних етапи, що повторюються періодично у часі [4]. Для реалізації способу контактні пристрої експериментальної колони були оснащені рухомими клапанами, які почергово закривали та відкривали переливні отвори згідно із заданим алгоритмом. Спосіб дає змогу змінювати швидкість пари у вільному перерізі колони та в щілинах контактних пристроїв завдяки зміні живого перерізу тарілок при сталому тиску в нижній i верхній частинах колони таким чином, що під час переливу рідини тарілка стає провальною.

Загальний вигляд тарілки із змінним живим перерізом, конструкція якої дає змогу подовжити час перебування рідини на ії полотні на заданий термін часу, показаний на рис. 2.

Мета статті: дослідження ефективності роботи контактних пристроїв із змінним живим перерізом у процесах розгонки головної фракції (ГФ) спирту етилового та перегонки зрілої бражки, ступеня очищення етилового спирту від супутніх летких домішок та концентрації етанолу в бражному дистиляті при подовженні часу перебування рідини на тарілках розгінної та бражної колон БРУ.

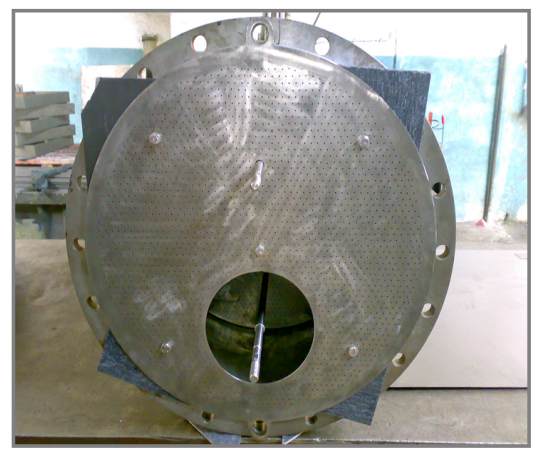

Рис. 2. Тарілка із змінним живим перерізом

Викладення основних результатів дослідження. Експериментальна колона з тарілками із змінним живим перерізом виготовлена співробітниками ТОВ «ТІСЕР» у співпраці з науковцями кафедри біотехнології продуктів бродіння і виноробства Національного університету харчових технологій. Дослідження проводились у виробничих умовах ДП «Чуднівський спиртовий завод».

Для вирішення поставленого завдання колона була оснащена лускоподібними тарілками 3 коаксіальним розташуванням лусок, що виключало односпрямованість руху рідини. Переливні отвори кожної тарілки почергово відкривали та закривали рухомі клапани, з'єднані з приводними механізмами відповідно до програми контролера [5]. Робочий цикл включав час рідинної затримки (контакту пари та рідини) та час переливу рідини. В кожному робочому циклі відбувалася зміна живого перерізу тарілок від 2,6\% в період масообміну до 51,7\% в момент переливу рідини з верхніх тарілок на нижні. Під час відкривання переливних отворів швидкість пари миттєво зменшувалась, що призводило до проливу рідини через переливні отвори та щілини лусок. Таким чином час переливу рідини 3 верхніх тарілок на нижні скорочувався від 5 до 2 сек. 
На першому етапі проводили дослідження ефективності роботи контактних пристроїв в процесі вилучення етилового спирту із спиртовмісних фракцій. На тарілку живлення розгінної колони (РК) подавали ГФ спирту етилового разом з сивушною фракцією в кількості 10\% від абсолютного алкоголю (а.а.) бражки. На верхню тарілку колони безперервно надходила гаряча пом'якшена вода для гідроселекції летких домішок. Концентрація етилового спирту в кубовій рідині становила $5 \ldots .6 \%$ об. Із конденсатора РК відбирали концентрат головної фракції (КГФ) в кількості 0,15\% від а.а. бражки, контролюючи якість ректифікованого спирту. Час затримки рідини на тарілках становив $20 \mathrm{c}$.

Для проведення хроматографічного аналізу відбирали проби кубової водно-спиртової рідини, флегми, КГФ та проби з рідинної фази $6,11,17,21,25-1$ тарілок через 72 години після зміни режиму роботи колони. Кожну серію дослідів проводили в триразовій повторності з інтервалом між дослідами 24 год. Визначальними обиралися середні величини. Отримані результати представлені в таблиці.

\section{Табличя. Розподілення ключових летких домішок етилового спирту по висоті РК}

\begin{tabular}{|c|c|c|c|c|c|c|c|c|}
\hline \multirow{3}{*}{ Домішки } & \multicolumn{8}{|c|}{ Концентрація летких сполук по тарілках, мг/дм ${ }^{3}$} \\
\hline & \multirow{2}{*}{$\begin{array}{l}\text { кубова } \\
\text { рідина }\end{array}$} & \multicolumn{5}{|c|}{ Номер тарілки } & \multirow{2}{*}{ флегма } & \multirow{2}{*}{ КГФ } \\
\hline & & T. 6 & T. 11 & T. 17 & т. 21 & т. 25 & & \\
\hline $\begin{array}{c}\text { Етиловий } \\
\text { спирт, \% об. }\end{array}$ & 5,0 & 13,8 & 14,1 & 15,0 & 11,2 & 7,0 & 55,1 & 68,0 \\
\hline $\begin{array}{c}\text { Альдегіди, в } \\
\text { т. ч. }\end{array}$ & 0,45 & 0,21 & 1,98 & 3,97 & 22,31 & 23,96 & 1358,53 & 2046,24 \\
\hline ацетальдегід & 0,45 & 0,21 & 1,98 & 3,97 & 22,31 & 23,96 & 1349,72 & 2032,70 \\
\hline кротоновий & сліди & сліди & сліди & сліди & сліди & сліди & 8,81 & 13,54 \\
\hline Естери, в т. ч. & сліди & сліди & сліди & 0,97 & 137,67 & 83,43 & 13293,62 & 16287,51 \\
\hline етилацетат & сліди & сліди & сліди & 0,97 & 128,96 & 70,97 & 13247,40 & 16242,76 \\
\hline етилбутират & сліди & сліди & сліди & сліди & 8,71 & 12,46 & 46,22 & 44,75 \\
\hline $\begin{array}{c}\text { Сивушне масло, } \\
\text { в т. ч. }\end{array}$ & 103,96 & 441,90 & 461,29 & 529,59 & 688,77 & 889,82 & 6168,71 & 4151,27 \\
\hline н-пропанол & 88,27 & 347,98 & 349,42 & 403,85 & 521,83 & 618,48 & 2062,67 & 1358,02 \\
\hline ізобутанол & 6,67 & 56,22 & 64,63 & 77,88 & 93,42 & 130,97 & 2432,19 & 1766,78 \\
\hline ізопентанол & 8,28 & 36,95 & 46,41 & 46,74 & 71,95 & 138,24 & 1642,61 & 999,87 \\
\hline ізопропанол & 0,74 & 0,75 & 0,83 & 1,12 & 1,57 & 2,13 & 31,24 & 26,54 \\
\hline Метанол, \% об. & 0,027 & 0,054 & 0,102 & 0,135 & 0,173 & 0,189 & 4,206 & 1,013 \\
\hline
\end{tabular}

Аналіз отриманих результатів показав, що при подовженні часу перебування рідини на тарілках РК до 20 с проміжні та кінцеві домішки спирту ефективно вилучалися разом з головними. В процесі розгонки найбільшу ступінь вилучення мали естери та альдегіди. Відомо, що домішки більшості естерів надають спирту неприємного запаху - смолисто-гнилісного, прогірклого, затхлого, прілого, кисло-сирного, паленого тощо. Такі домішки, як пропілацетат, етилпропіонат, етилбутират характерні для спирту, виробленого із неякісної зернової сировини. До складу такого спирту можуть входити етилформіат і пропілформіат. Вони придають спирту відтінки від пліснявілих до кисло-смолисто-затхлих запахів. У процесі ректифікації ці домішки вилучити складно, оскільки їх леткість близька до леткості етилового спирту. Зазвичай, кількість естерів у 
ректифікованому спирті із крохмалевмісної сировини майже в п'ять разів перевищує суму вищих спиртів та альдегідів.

Як видно із табл. 1, до складу естерів, що містяться в ГФ, входять етилацетат і в меншій кількості етилбутират. Етилбутират надає товарному спирту різкий запах. Практично доведено, що запропонований спосіб забезпечує його повне видалення. Відсутність етилформіату свідчить про відповідну якість зернової сировини.

Альдегіди також характеризуються різким запахом. При взаємодії альдегідів і спиртів утворюються ацеталі та напівацеталі, які, крім ацеталів оцтового, пропіонового та масляного альдегідів, погіршують якість спирту. В ректифікованому спирті допускається наявність ацетальдегіду, який у нормативних кількостях суттєво не впливає на його органолептичні показники.

Кротоновий альдегід, як і акролеїн, відноситься до ненасичених альдегідів, має гострий запах і неприємний смак. В умовах глибокої гідроселекції в режимі циклічної ректифікації кротоновий альдегід повністю видаляється із кубової рідини.

Разом з естерами та альдегідами високий ступінь вилучення мали вищі спирти сивушного масла: ізопропанол, н-пропанол, ізобутанол, ізопентанол та н-бутанол. Ці проміжні домішки разом з метиловим спиртом більше концентрувались у дефлегматорі колони. Відомо, що метиловий спирт утворюється в результаті термічного розпаду пектинових речовин при тепловій обробці сировини та в незначних кількостях в процесі бродіння. Метанол відноситься до кінцевих домішок і, на відміну від головних, вилучається із висококонцентрованих розчинів, в яких вміст етилового спирту становить $60 \%$ мас. і більше [1]. Незважаючи на це, отримані практичні результати свідчать про високий ступінь вилучення та кратність його концентрування при використанні запропонованого способу в режимі глибокої гідроселекції.

Витрати гріючої пари $\left(G_{\text {п }}\right)$ при роботі РК в режимі контрольованих циклів затримки рідини на ії тарілках розраховували, виходячи із теплового балансу за витратами води на охолодження та ії температурою на вході у конденсатор і після дефлегматора, за формулою:

$$
G_{\text {п }}=\frac{\mathrm{G}_{\mathrm{B}} c_{\mathrm{B}}\left(t_{2}-t_{1}\right)}{r} \cdot 1,05=103 \text { кг/год, }
$$

де $G_{\text {в }}$ - витрати води на охолодження, дм³/год, $G_{\text {в }}=1058$ дм $^{3} /$ год; $G_{\text {в }}$ теплоємність води, $C_{\text {в }}=4,19$ кДж/(кг·град); $t_{1}$ - температура води в колекторі, ${ }^{\circ} \mathrm{C}, t_{1}=15^{\circ} \mathrm{C} ; t_{2}-$ температура води після дефлегматора, ${ }^{\circ} \mathrm{C}$, $t_{2}=65^{\circ} \mathrm{C} ; r$ - прихована теплота пароутворення при тиску 101,3 кПа (для води $r=2256$ кДж/кг); 1,05 - коефіцієнт, який враховує втрати тепла гріючої пари по висоті РК з урахуванням ізоляції її обичайок.

Питому витрату гріючої пари ( $G_{\text {пит }}^{\text {пг }}$ кгдал а. а.,, введеного на тарілку живлення), розраховували за формулою:

$$
G_{\text {пा }}^{\text {пит }}=\frac{G_{\text {п }}}{V_{Г Ф} \mathrm{C}_{\Gamma \Phi}} \cdot 100=13 \text { кг/дал а. а.; }
$$


де $V_{\text {ГФ }}$ - витрата ГФ спирту етилового, дал/год, $V_{\text {ГФ }}=8,5$ дал/год; $C_{\Gamma \Phi}-$ концентрація етилового спирту в ГФ, \%об., $C_{\Gamma Ф}=93,3 \%$ об.

У процесі розгонки ГФ при затримці рідини на тарілках до 20 с ступінь вилучення альдегідів, вищих спиртів сивушного масла та метилового спирту зростала в середньому на $30 \%$, кратність концентрування головних і верхніх проміжних домішок підвищувалась на $32 \%$. При цьому витрати гріючої пари на процес розгонки скорочувались на $30 \%$ порівняно з типовими установками до 13 кг/дал а.а., введеного на тарілку живлення РК.

На другому етапі проводились дослідження ефективності запропонованої авторами технології в процесі перегонки зрілої бражки. Встановлено, що подовження часу перебування бражки на тарілках експериментальної колони до 12 с дає змогу підвищити концентрацію спирту в бражному дистиляті до $63 . .65 \%$ об. порівняно 3 типовими бражними колонами. Коаксіальне розташування лусок виключає можливість утворення застійних зон і пригорання зважених частинок бражки, що подовжує експлуатаційний період роботи бражної колони без зупинки на профілактичні роботи [6].

Встановлено, що витрати гріючої пари на процес брагоперегонки скорочуються на $35 \%$ порівняно з типовими бражними колонами і не перевищують 16 кг/дал а.а. бражки.

\section{Висновки}

Використання тарілок із змінним живим перерізом у БРУ дає змогу реалізувати переваги режиму повного витіснення за парою і рідиною та унеможливити перемішування рідини на суміжних тарілках. Подовження часу перебування рідини на тарілках бражної та розгінної колон до 12 і 20 с відповідно наближає ефективність їх роботи до ефективності теоретичних тарілок. При цьому ступінь розділення спиртовмісних фракцій зростає на $30 \%$, концентрація спирту в бражному дистиляті підвищується на $28 \%$, а витрати гріючої пари скорочуються в середньому на $32 \%$ порівняно з типовими установками. Крім того, час переливання рідини по тарілках зменшується від 5 до 2 с завдяки миттєвому зменшенню швидкості пари в щілинах контактних пристроїв.

Перспективним напрямком є дослідження ефективності роботи контактних пристроїв із змінним живим перерізом у процесах епюрації бражного дистиляту й очистки етилового спирту.

\section{Література}

1. Шиян П.Л., Сосницький В.В., Олійнічук С.Т. Інноваційні технології спиртової промисловості. Теорія і практика: монографія. Київ: Видавничий дім «Асканія», 2009. 424 с.

2. Цыганков П.С., Цыганков С.П. Руководство по ректификации спирта. Москва: ПИЩЕПРОМИЗДАТ, 2001. 400 с.

3. Buliy Y., Shiyan P., Kuts A. Distillation of alcoholic distillate in controlled cycles mode. 8th Central European Congress on food 2016. Food Science for Well-deing (CEFood 2016): Book of Abstracts. 23-26 May 2016. Kyiv: NUFT, 2016. P. 230.

4. Спосіб переливу рідини по тарілках колонного апарата у процесі масообміну між парою та рідиною: пат. 89874 С2. Україна; заявлено 06.06.08; Опубл. 10.03.10, Бюл. № 5.4 с.

5. Ректифікаційна колона 3 керованими циклами: пат. 116565 Україна; заявлено 12.12.16; Опубл. 25.05.17, Бюл. № 10.5 с.

6. Булий Ю.В., Шиян П.Л., Дмитрук А.П., Куц А.М. Оптимизация процесса перегонки спиртовой бражки. Химия и технология пищи. Каунас: ПИКТУ, 2015. Т. 49, № 1. С. 20-28. 